\title{
Physiological changes in hybrid Brachiaria cv. Mulato II after accelerated aging to overcome dormancy ${ }^{1}$
}

\author{
Diego de Sousa Pereira ${ }^{2 *}$, Maria Laene Moreira de Carvalho ${ }^{2}$, Renato Mendes \\ Guimarães ${ }^{2}$, Ariadne Santos Oliveira², Gabriel Abreu Reis ${ }^{2}$
}

\begin{abstract}
To evaluate the effect of accelerated aging to overcome dormancy of hybrid Brachiaria cv. Mulato II (U. brizantha $\mathrm{x} U$. decumbens $\mathrm{x} U$. ruziziensis), seeds were collected from two lots with and without scarification, submitted to 42 ${ }^{\circ} \mathrm{C}$ and high humidity (98\%) for different periods $\left(0,24,48,72\right.$ and $96 \mathrm{~h}$ ) and then dried at $30{ }^{\circ} \mathrm{C}$ to the humidity of $9.1 \%$. The physiological changes were evaluated by tetrazolium, germination, electrical conductivity, respiratory activity and enzymatic evaluation. The exposure of the hybrid Brachiaria cv. Mulato II to accelerated aging at $42{ }^{\circ} \mathrm{C}$ and $98 \%$ relative air humidity for up to 96 hours does not alter its viability by the tetrazolium test. Accelerated aging at $42{ }^{\circ} \mathrm{C}$ and $98 \%$ of humidity for up to 48 hours favors the germination of the scarified seeds of hybrid Brachiaria cv. Mulato II, with increased expression of $\alpha$-amylase enzyme and reduction of electrical conductivity values. Loss of vigor occurs in scarified seeds of hybrid Brachiaria cv. Mulato II when exposed to accelerated aging at $42{ }^{\circ} \mathrm{C}$ and $98 \%$ of humidity from 96 hours with consequent changes in enzymatic systems and increased of the respiratory rate.
\end{abstract}

Index terms: forage seeds, germination, electrical conductivity, respiration, isoenzymes.

\section{Alterações fisiológicas em sementes de Braquiária híbrida cv. Mulato II após envelhecimento acelerado para a superação da dormência}

\begin{abstract}
RESUMO - Para avaliar o efeito do envelhecimento acelerado para a superação da dormência de Braquiária híbrida cv. Mulato II (U. brizantha x U. decumbens x U. ruziziensis), foram utilizadas sementes de dois lotes com e sem escarificação, submetidas a temperatura de $42{ }^{\circ} \mathrm{C}$ e alta umidade $(98 \%)$ por diferentes períodos $(0,24,48,72$ e $96 \mathrm{~h})$ e posteriormente secadas a $30^{\circ} \mathrm{C}$ até a umidade de $9,1 \%$. As alterações fisiológicas foram avaliadas pelos testes de tetrazólio, germinação, condutividade elétrica, atividade respiratória e avaliação enzimática. A submissão das sementes de Braquiária híbrida cv. Mulato II ao envelhecimento acelerado a $42{ }^{\circ} \mathrm{Ce} 98 \%$ de umidade relativa do ar por até 96 horas não altera a sua viabilidade pelo teste de tetrazólio. O envelhecimento acelerado a $42{ }^{\circ} \mathrm{C}$ e $98 \%$ de umidade relativa do ar por até 48 horas favorecem a germinação das sementes escarificadas de Braquiária híbrida cv. Mulato II, com aumento da expressão da enzima $\alpha$-amilase e redução dos valores de condutividade elétrica. Ocorre perda de vigor nas sementes escarificadas de Braquiária híbrida cv. Mulato II quando são expostas ao envelhecimento acelerado a $42{ }^{\circ} \mathrm{Ce} 98 \%$ de umidade relativa do ar a partir de $96 \mathrm{~h}$, com consequentes alterações nos sistemas enzimáticos e aumento da taxa respiratória.
\end{abstract}

Termos para indexação: sementes de forrageira, germinação, condutividade elétrica, respiração, isoenzimas.

\section{Introduction}

Among the species of tropical forage used in Brazil, the genus Urochloa (Brachiaria) is one of the main sources of nutrients in animal feed, providing fibers, energy, proteins, minerals and vitamins (Santos et al., 2011; Teodoro et al., 2012; Euclides et al., 2016). Due to the importance of forage species, it is relevant to improve the technologies to add higher quality seeds, which has a direct relationship with pasture formation, thus ensuring a faster response to the investments

\footnotetext{
${ }^{1}$ Submitted on 10/31/2016. Accepted for publication on $05 / 10 / 2017$.

${ }^{2}$ Departamento de Agricultura, UFLA, Caixa Postal 3037, 37200-000 - Lavras, MG, Brasil.

*Corresponding author <diegobizi@gmail.com>
} 
made in the production process (Martins and Silva, 2003; Meschede et al., 2004; Quadros et al., 2012).

The cultivar Mulato II is the first hybrid of Brachiaria marketed in Brazil, and it was developed from the crossing of three species of Urochloa (U. brizantha $\mathrm{x} U$. decumbens $\mathrm{x} U$. ruziziensis). This cultivar have characteristics of resistance to the spittlebug (Zulia entreriana, Deois fravopicta and Deois schac), to prolonged droughts, high temperatures, acid soils, besides responding well to grazing and nitrogen fertilization (Ricaurte et al., 2007; Teodoro et al., 2012; Ramos and Vital, 2016). Since it is a recently released material, research on this hybrid seed is still scarce.

Despite the agronomic advantages, the seeds of this hybrid species, as well as the other Brachiarias, present dormancy (Costa et al., 2011). However, the dormancy mechanism has peculiarities for different species, making it difficult to generalize about its causes, which may occur independently or in combination, as is the case for most seeds of forage grasses (Previero et al., 1998, Santos et al., 2011).

According to Whiteman and Mendra (1982), dormancy in Urochloa seeds is controlled by two mechanisms, the physiological dormancy present in freshly harvested seeds and the mechanical dormancy imposed by the wrappings, related to the restrictions of the entry of oxygen and water in the seeds. The physiological dormancy associated with the embryo is progressively suppressed during storage and the mechanical dormancy imposed to the embryo persists in seeds storage for long periods. Despite the evident importance of dormancy in freshly harvested seeds, the mechanisms that are involved in overcoming dormancy that occurs during storage are still poorly elucidated.

Because of this, some methods are recommended for the total overcoming of seed dormancy, such as chemical treatments, mechanical scarification and heat treatments with the use of elevated temperatures. For seeds of Brachiaria, chemical scarification with sulfuric acid has been recommended (Silva et al., 2014), but it presents operational risks to workers, pollutes the environment and, in addition, can promote qualitative damage to seeds (Usberti and Martins, 2007). Thus, mechanical scarification presents advantages by removing the external structures of the seeds, facilitating gas exchange by the seeds (Zuffo et al., 2014). In addition to the scarification methodologies, researches that evaluates the dormancy overcoming process of forage grass seeds, has considered the action of high temperatures and high humidity (Pereira et al., 2014; Lacerda et al., 2010). It has beneficial effect, as can be observed by the results obtained to overcome dormancy in seed lots of Brachiaria brizantha cv. Marquise et al., 2004), Brachiaria plantaginea (Link) and Hitchc. (Freitas et al., 1990) and Brachiaria decumbens
(Usberti et al., 1990). As seen before, the objective of this study was to evaluate the influence of accelerated aging on the dormancy overcoming of hybrid Brachiaria cv. Mulato II with and without mechanical scarification.

\section{Material and Methods}

Two lots of hybrid Brachiaria cv. Mulato II (with and without mechanical friction scarification on rubber rollers) produced by Dow Agrosciences Sementes \& Biotecnologia Brasil Ltda. The seeds of each lot were homogenized and submitted to artificial aging on an aluminum screen fixed in gerbox-type plastic boxes containing $40 \mathrm{~mL}$ of distilled water and conditioned in BOD type germination chambers at $42{ }^{\circ} \mathrm{C}$ for 0, 24, 48, 72 and 96 hours (Oliveira et al., 2016).

After the storage period, the seeds were dried in a forced air circulation oven, with constant temperature of $30^{\circ} \mathrm{C}$ for 24 hours until the initial water content has reached $9.1 \%$. After drying, the physiological quality of the seeds was evaluated by the following tests:

Germination test: As substrate, blotting paper was used, in gerboxes, moistened with 2.5 times the dry mass of the paper in distilled water. The seeds were kept in BOD with alternating temperature $20-35{ }^{\circ} \mathrm{C}$ and photoperiod of $8 \mathrm{~h}$ with light and $16 \mathrm{~h}$ in the dark, counting normal seedlings according to the Rules for Seed Analysis (Brasil, 2009) on the seventh day (First count), final count on the twenty-first, plus an intermediate count on the fourteenth day after sowing.

Tetrazolium test: The seeds were pre-soaked between filter paper moistened with 2.5 times the weight of the paper in distilled water and kept in a germinator with the temperature at $30{ }^{\circ} \mathrm{C}$ for 18 hours; After that period, the seeds were cut lengthwise with the aid of a clamp and scalpel. After cut, the seeds were placed in a solution of $1.0 \%$ of chloride 2-3-5 triphenyl tetrazolium in dark bottles and kept in germination chambers type BOD with constant temperature of $30{ }^{\circ} \mathrm{C}$ for 2 hours (Brasil, 2009). The seeds were evaluated considering the location and intensity of the staining of their structures in viable and non-viable seeds.

Electrical conductivity of seeds - the seeds were weighed and soaked in $50 \mathrm{~mL}$ deionized water in disposable plastic cups and kept in BOD with a temperature of $25^{\circ} \mathrm{C}$ for 24 hours. After the imbibition period, the electrical conductivity was measured using the MS TECNOPON ${ }^{\circledR}$ conductivity meter, model mCA 150 . The results were expressed in $\mu \mathrm{S} \mathrm{cm}^{-1} \cdot \mathrm{g}^{-1}$ of seeds (Oliveira et al., 2016).

Analysis of respiratory activity - the seeds were weighed and sowed in a single sheet of germitest paper $(11 \mathrm{x} 11 \mathrm{~cm})$, moistened with 2.5 times the weight of the 
paper in distilled water. After sowing, the rolls of papers were placed in Falcon tubes $(50 \mathrm{~mL})$ with the gap in the cap sealed with a specific rubber, preventing gaseous exchanges with the environment, but allowing the entry of a needle to withdrawal the air through the CHECKPOINT $\mathrm{O}_{2} / \mathrm{CO}_{2}$ PBS - Dansensor. This sensor works with an electrochemical reader that absorbs a $15 \mathrm{ml}$ aliquot of the sample's atmosphere and instantly reads the percentage of carbon dioxide $\left(\mathrm{CO}_{2}\right)$ and oxygen $\left(\mathrm{O}_{2}\right)$. The values of carbon dioxide obtained in the readings were later divided by the mass of seeds present in the tube and the time from the sealing to the final reading, performed after $24 \mathrm{~h}$, the results expressed in $\% \mathrm{CO}_{2} \cdot \mathrm{g}^{-1} \cdot \mathrm{h}^{-1}$. As a calibration measure, four Falcon tubes containing only the germitest paper sheet moistened without the seeds were kept (Blank Assay).

Isoenzymatic analysis - After aging and drying, two grams of seeds were macerated with antioxidant polyvinylpyrrolidone (PVP) in liquid nitrogen. $100 \mathrm{mg}$ of subsamples from the macerated material and 250 $\mu \mathrm{L}$ of the extraction buffer $(0.2 \mathrm{M}$ Tris $\mathrm{HCl} \mathrm{pH} 8.0+$ $0.1 \% \beta$-mercaptoethanol) were weighed. The material was refrigerated $\left(4{ }^{\circ} \mathrm{C}\right)$ for $12 \mathrm{~h}$ and then centrifuged at $14,000 \mathrm{rpm}$ for 30 minutes at $4{ }^{\circ} \mathrm{C}$. Electrophoresis in polyacrylamide gels was developed in a discontinuous system (4.5\% concentration gel and $7.5 \%$ separation gel). The gel / electrode buffer system used was Tris-glycine $\mathrm{pH}$ 8.9. To perform the electrophoretic run, $50 \mu \mathrm{L}$ of the supernatant from each sample was run in the gutter channel and run at $4{ }^{\circ} \mathrm{C}$ for four hours at a constant voltage of $150 \mathrm{~V}$ (Agustini et al., 2016). At the end of the run, the gels were developed for the enzymes Malate dehydrogenase (MDH), Alcohol dehydrogenase (ADH), Catalase (CAT), Superoxide dismutase (SOD), Esterase (EST) and $\alpha$-amylase according to the protocols contained in Alfenas (2006). For evaluation of the $\alpha$-amylase enzyme, one gram of the seeds samples was previously soaked in filter paper moistened with 2.5 times the weight of the paper in distilled water for $48 \mathrm{~h}$ prior to maceration. To evaluate the enzymatic expression, enzymograms were constructed in the Microsoft Paint ${ }^{\circledR}$ computational application for the gel photographs.

Statistical procedure - a completely randomized design was used, with four replicates of 50 seeds, in a $2 \times 2 \times 5$ factorial scheme, two seed lots, without and with mechanical scarification, were submitted to five periods of dormancy overcoming with high temperature and humidity, 0, 24, 48, 72 and 96 hours. The means were submitted to analysis of variance and the results analyzed by regression analysis for quantitative data and for qualitative data, average comparison by the Tukey test at $5 \%$ of probability.

\section{Results and Discussion}

For the first germination count, germination percentage and electrical conductivity, in addition to the effects of each treatment, the physiological quality of the seeds is influenced differently by the scarification of the seeds and by the time of exposure to accelerated aging, given the significant interaction between these factors. For respiratory activity, there is influence on the physiological quality of the lots according to the scarification of the seeds when subjected to accelerated aging. For the results of the seed viability obtained by the tetrazolium test, only variation among the seed lots used was observed.

From the results of viability (Table 1), it can be observed that Lot 1 has the highest percentage of viable seeds in relation to Lot 2 and that the exposure of the seeds to the accelerated aging did not change their viability.

The scarification influenced the germination speed by the first count results, observing differences between the lots and scarification treatments (Table 2). However, this scarification effect was not observed for the lots in the germination percentage, this reinforced the evidence that in addition to the tegumentary dormancy, the cultivar Mulato II present physiological dormancy to the embryo as observed for the other species of Brachiaria. There was an effect of both artificial aging and scarification on seed germination, regardless of the lot evaluated (Table 3).

Scarification did not change the germination percentage of the seeds. However, from $24 \mathrm{~h}$ of exposure to accelerated aging, the scarified seeds germinated more rapidly. This

Table 1. Percentage of viable seeds obtained in the tetrazolium test in hybrid Brachiaria cv. Mulato II without and with scarification, subjected to accelerated aging.

\begin{tabular}{cccc}
\hline \multirow{3}{*}{ Aging } & Scarification & \multicolumn{2}{c}{ Viable } \\
\cline { 3 - 4 } & & 1 & 2 \\
\cline { 3 - 4 } & Without & 76 & 67 \\
\multirow{2}{*}{0} & With & 78 & 60 \\
\hline \multirow{2}{*}{24} & Without & 72 & 64 \\
& With & 77 & 63 \\
\hline \multirow{2}{*}{48} & Without & 72 & 65 \\
& With & 70 & 62 \\
\hline \multirow{2}{*}{72} & Without & 72 & 64 \\
& With & 72 & 66 \\
\hline \multirow{2}{*}{96} & Without & 75 & 64 \\
& With & 73 & 66 \\
\hline \multirow{2}{*}{ Average } & & $74 \mathrm{~A}$ & $64 \mathrm{~B}$ \\
\hline
\end{tabular}

Means followed by the same letter do not differ by Tukey test at $5 \%$ probability. 
behavior was maintained up to $72 \mathrm{~h}$, when there was an inversion of values, when the seeds that were not scarified had a higher germination speed, probably due to the greater capacity of water and oxygen absorption promoted by accelerated aging. In relation to germination, there was superiority of values for scarified seeds, even before aging (Table 3). At 96h of aging, this behavior, like the first count, was altered, indicating a more drastic effect of the accelerated aging on the seeds that no longer had protection structures,

Table 2. First germination count and percentage of germination in seed lots of hybrid Brachiaria cv. Mulato II without and with scarification.

\begin{tabular}{|c|c|c|c|}
\hline \multicolumn{4}{|c|}{ First germination count $(\%)$} \\
\hline \multirow{2}{*}{ Lots } & \multicolumn{2}{|c|}{ Scarification } & \multirow{2}{*}{ Average } \\
\hline & Without & With & \\
\hline 1 & 30 & 42 & $36 \mathrm{~B}$ \\
\hline 2 & 41 & 51 & $46 \mathrm{~A}$ \\
\hline Average & $35 \mathrm{~b}$ & $47 \mathrm{a}$ & \\
\hline \multicolumn{4}{|c|}{ Germination (\%) } \\
\hline \multirow[t]{2}{*}{ Lots } & Scarif & & \multirow{2}{*}{ Average } \\
\hline & Without & With & \\
\hline 1 & 47 & 55 & $51 \mathrm{~A}$ \\
\hline 2 & 48 & 61 & $54 \mathrm{~A}$ \\
\hline Average & $47 \mathrm{~b}$ & $58 \mathrm{a}$ & \\
\hline
\end{tabular}

Means followed by the same letter, upper case in the columns for each test and lowercase in the lines, for the first count and final germination, do not differ among themselves by the Tukey test at $5 \%$ probability.

Table 3. First germination count, percentage of germination and remaining viable seeds of the germination test of hybrid Brachiaria cv. Mulato II without and with scarification submitted to accelerated aging.

\begin{tabular}{|c|c|c|c|c|c|}
\hline \multicolumn{6}{|c|}{ First germination count $(\%)$} \\
\hline \multirow{2}{*}{ Scarification } & \multicolumn{5}{|c|}{ Artificial Aging (Hours) } \\
\hline & 0 & 24 & 48 & 72 & 96 \\
\hline Without & $39 \mathrm{~A}$ & $30 \mathrm{~B}$ & $31 \mathrm{~B}$ & $31 \mathrm{~B}$ & $44 \mathrm{~A}$ \\
\hline With & $45 \mathrm{~A}$ & $44 \mathrm{~A}$ & $54 \mathrm{~A}$ & $50 \mathrm{~A}$ & $40 \mathrm{~B}$ \\
\hline \multicolumn{6}{|c|}{ Germination $(\%)$} \\
\hline \multirow{2}{*}{ Scarification } & \multicolumn{5}{|c|}{ Artificial Aging (Hours) } \\
\hline & 0 & 24 & 48 & 72 & 96 \\
\hline Without & $49 \mathrm{~B}$ & $42 \mathrm{~B}$ & $44 \mathrm{~B}$ & $47 \mathrm{~B}$ & $54 \mathrm{~A}$ \\
\hline With & $61 \mathrm{~A}$ & $60 \mathrm{~A}$ & $66 \mathrm{~A}$ & $60 \mathrm{~A}$ & $46 \mathrm{~B}$ \\
\hline \multicolumn{6}{|c|}{ Remaining germination viable (\%) } \\
\hline \multirow{2}{*}{ Scarification } & \multicolumn{5}{|c|}{ Artificial Aging (Hours) } \\
\hline & 0 & 24 & 48 & 72 & 96 \\
\hline Without & 10 & 13 & 12 & 11 & 8 \\
\hline With & 5 & 5 & 5 & 5 & 2 \\
\hline
\end{tabular}

Means followed by the same letter, upper case in the columns, for the first count and final germination, do not differ by Tukey test at $5 \%$ probability. removed in the scarification process.

Similar results were obtained by Meschede et al. (2004) for seeds of $U$. brizantha cultivar Marandu aged for 60h. In $U$. plantaginea, Freitas et al. (1990) observed that seeds submitted to heat treatment at $40{ }^{\circ} \mathrm{C}$ for four weeks had their germination increased, while seeds maintained at $4{ }^{\circ} \mathrm{C}$ maintained the same degree of dormancy. In the same sense regarding dormancy in Brachiaria seeds, Vieira; Silva and Barros (1998) recommend the pre-heating of seeds at $70{ }^{\circ} \mathrm{C}$ or artificial aging at $42{ }^{\circ} \mathrm{C}$, both for $72 \mathrm{~h}$, as efficient in overcoming dormancy of $U$. brizantha seeds.

The analysis of the viable remaining seeds indicates a positive effect of scarification and accelerated aging on seed germination, but did not completely eliminate dormant seeds (Table 3). These results lead us to believe that there is more than one dormancy mechanism that regulates the germination of Mulato II cultivar in addition to gas impermeability, like other Brachiaria species, as mentioned by Freitas et al. (1990) and Sallum et al. (2010).

There is a trend to increased germination speed promoted by the increased of the seed permeability in scarified seeds and a reduction in non-scarified between 24 and $72 \mathrm{~h}$ after exposure to accelerated aging (Figures 1A and 1B). Differences between the lots for germination and tetrazolium values were observed due to seed dormancy, even after the scarification process. In seeds of $U$. brizantha $\mathrm{cv}$. Marandu, a similar effect was observed by Custódio et al. (2012), who emphasize that seed dormancy in Brachiaria species is caused by different factors, which may occur in isolation or in combination (Meschede et al., 2004; Dias and Alves, 2008, Gaspar-Oliveira et al., 2008; Sallum et al., 2010).

Differences in germination values between scarified and non-scarified Brachiaria seeds were also observed by Marchi et al. (2008) and Santos et al. (2011) for U. brizantha cv. Piatã and U. dictyoneura (Almeida and Silva, 2004). That is evidencing that the presence of dormancy is a common feature among Brachiaria species, which includes Mulato II cultivar, and that scarification is beneficial to seed germination.

The beneficial effect of the exposure to accelerated aging on the germination Mulato II cultivar of scarified seeds was also evidenced by the increase of $\alpha$-amylase enzyme expression in the seed lots evaluated (Figure 2).

Differently, for seeds without chiseling, the increase in $\alpha$-amylase enzyme expression occurs from $48 \mathrm{~h}$, in the same way as there were increases in germination values after this period and until the end of the exposure to accelerated aging (Figure 1B). This increase in the expression of the $\alpha$-amylase enzyme is directly related to high seed quality, since this enzyme is responsible for up to $90 \%$ of the amylolytic activity in seeds that have starch as the main reserve component, such 
First germination count

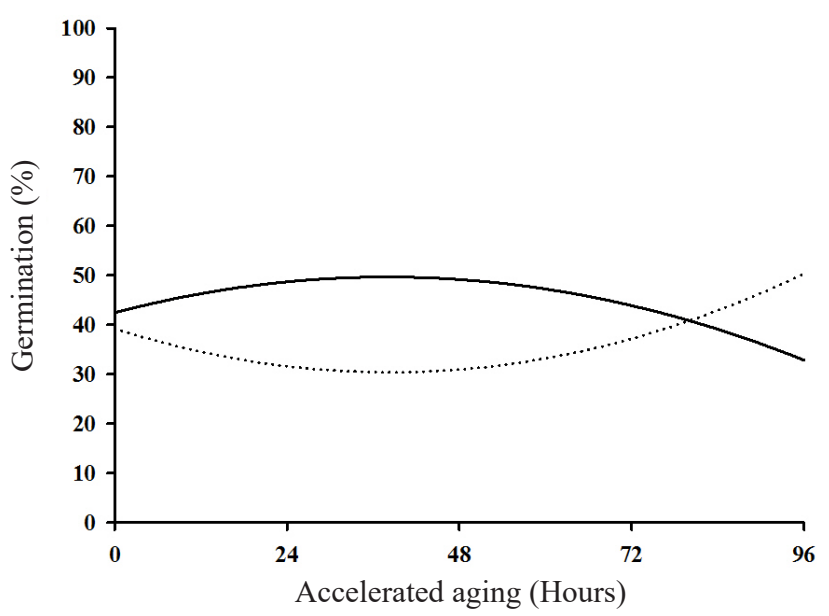

With scarification $\mathrm{Y}=42.46 * *+0.38 * * \mathrm{x}-0.005 * \mathrm{x}^{2} ; \mathrm{R}^{2}=82.46 \%$ ....... Without scarification $\mathrm{Y}=39.20 * *-0.46 * \mathrm{x}+0.006 * * \mathrm{x}^{2} ; \mathrm{R}^{2}=92.74 \%$
Germination

B

Figure 1. Percentage of germination, in the first count (A) and final germination (B), of hybrid Brachiaria cv. Mulato II seeds without and with scarification submitted to accelerated aging.

as Brachiaria seeds. When promoting starch breakdown, the carbohydrate supply necessary for the development of the embryo occurs (Franco et al., 2002).

Another beneficial effect observed in the evaluation of the seeds of the Mulato II cultivar, besides those observed in the germination, refers to the values of electrical conductivity (Figure 3). There was a reduction in the amount of leachate from the seeds of Lot 1 compared to the seeds from lot 2, which maintained the values of conductivity unchanged throughout the artificial aging (Figure 3A).

Regarding the electrical conductivity for the seeds without scarification (Figure 3B), a reduction in the amount of leachate occurred up to $48 \mathrm{~h}$, increasing with the increase of artificial aging. For the scarified seeds, seeds without chiseling had lower electrical conductivity values and these values decrease linearly until the end of the exposure time of the seeds to the accelerated aging. That is evidencing a probable cellular repair, in accordance with the results obtained by authors such as Vieira and Silva and Barros (1998), Martins and Silva (2003), Meschede et al. (2004), Previero et al. (1998), Santos et al. (2011), working with other Brachiaria species.

It is believed that the difference between the values of electrical conductivity for seeds without and with scarification can be due to the high content of impurities coming from the field of production that the wrapping layers can be adhered to the seeds without scarification. Since these layers were partially removed with the mechanical scarification process, altering the permeability of the enveloping layers. Besides

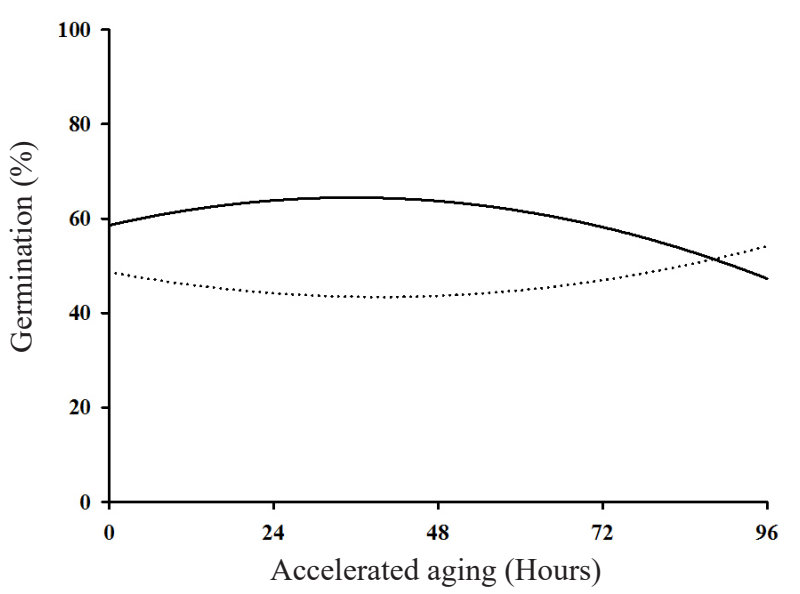

With scarification $\mathrm{Y}=58.56 * *+0.34 * \mathrm{x}-0.0047 * * \mathrm{x}^{2} ; \mathrm{R}^{2}=81.06 \%$

...... Without scarification $\mathrm{Y}=48.65 * *-0.27 * \mathrm{x}+0.0033 * \mathrm{x}^{2} ; \mathrm{R}^{2}=95.61 \%$ changes in the electrical conductivity values, changes in the respiratory activity of the seeds were also observed.

Differences in the respiratory rate of seeds occurred at each time of exposure to accelerated aging between seed lots without and with scarification (Table 4). The highest concentrations of $\mathrm{CO}_{2}$ were observed in Lot 1 for scarified seeds. In the second lot, differences in $\mathrm{CO}_{2}$ concentrations are observed between seeds with and without scarification up to $48 \mathrm{~h}$. In general, for the evaluated lots the scarified seeds have higher respiratory activity in relation to the seeds without scarification.

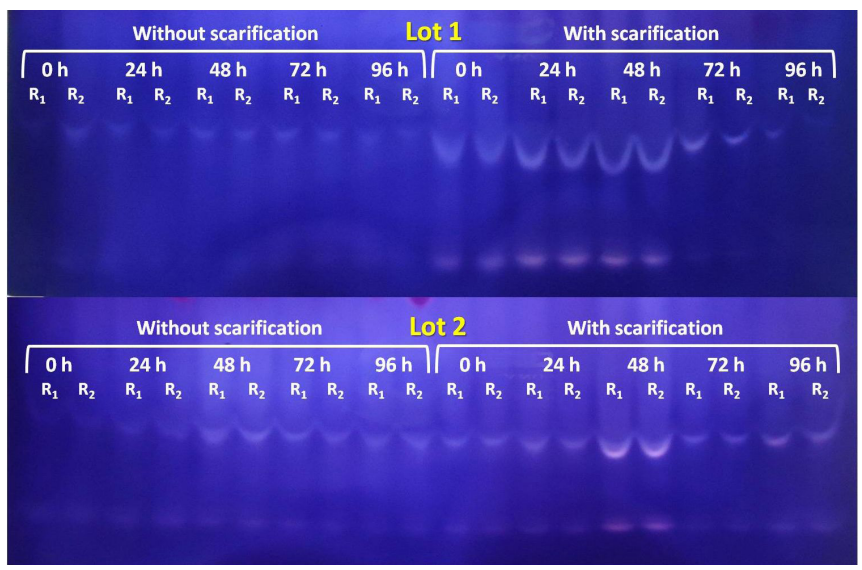

Figure 2. Expression of $\alpha$-amylase enzyme extracted from hybrid Brachiaria cv. Mulato II without and with scarification submitted to accelerate aging. 
Electrical conductivity

A



Electrical conductivity

B



Figure 3. Electrical conductivity between lots (A) of hybrid Brachiaria cv. Mulato II and for seeds without and with scarification (B) subjected to accelerated aging.

In Lot 1 , the increase in respiratory activity occurs steadily for scarified seeds. For seeds without chiseling, the increase in $\mathrm{CO}_{2}$ concentration occurs up to $48 \mathrm{~h}$ of artificial aging, when it is decreasing (Figure 4A).

In lot 2 , the respiratory activity of the seeds was higher in the scarified seeds than the one observed for the seeds without scarification, with the values constant throughout the periods of artificial aging. In addition, the respiratory activity of the seeds without scarification increases at constant rates, similar to that of scarified seeds at the end of 96h (Figure 4B). Similar to that observed for respiratory activity, there was an increase in the expression of isoenzymes involved in the cellular respiratory process up to $48 \mathrm{~h}$ for Lot 1 and, up to $72 \mathrm{~h}$ for Lot 2 , as can be observed in the zymogram of the MDH and ADH enzymes (Figure 5).

For Lot 1, the expression of the enzyme Malate dehydrogenase, as well as the concentration of carbon dioxide, has its highest expression at $48 \mathrm{~h}$ (Figure 5A), with reduction in subsequent times, data coincident with the concentration of Carbon Dioxide. The scarified seeds of Lot 1 showed higher expression of the MDH enzyme up to $72 \mathrm{~h}$ with reduction at the end in 96h (Figure 5A).

In Lot 2, seeds without chiseling, there was an increase in the expression of the MDH enzyme with the increase of accelerated aging for up to $72 \mathrm{~h}$. For the scarified seeds, there is a greater expression of the MDH enzyme after $24 \mathrm{~h}$ of exposure to high temperature and humidity (Figure
5A). For the enzyme Alcohol dehydrogenase, an increase in expression is observed from $72 \mathrm{~h}$ for the seeds of Lot 1 without scarification, when scarified this increase occurred from 48h. For Lot 2, the increase in ADH expression also occurs differently between seeds with and without scarification. For the seeds without scarification, the highest expression observed from $48 \mathrm{~h}$ and, for scarified seeds, from $24 \mathrm{~h}$ of exposure to accelerated aging (Figure $5 \mathrm{~B}$ ).

Table 4. Respiratory activity $\left(\% \mathrm{CO}_{2} \cdot \mathrm{g}^{-1} \cdot \mathrm{h}^{-1}\right)$ evaluated in seed lots of hybrid Brachiaria cv. Mulato II without and with scarification submitted to accelerated aging.

\begin{tabular}{cccc}
\hline \multirow{2}{*}{ Aging } & \multirow{2}{*}{ Scarification } & \multicolumn{2}{c}{ Lots } \\
\cline { 3 - 4 } & & 1 & 2 \\
\hline \multirow{2}{*}{$0 \mathrm{~h}$} & Without & $0.33 \mathrm{Ba}$ & $0.26 \mathrm{Ba}$ \\
& With & $0.56 \mathrm{Aa}$ & $0.43 \mathrm{Aa}$ \\
\hline \multirow{2}{*}{$24 \mathrm{~h}$} & Without & $0.56 \mathrm{Ba}$ & $0.36 \mathrm{Bb}$ \\
& With & $0.96 \mathrm{Aa}$ & $0.50 \mathrm{Ab}$ \\
\hline \multirow{2}{*}{$48 \mathrm{~h}$} & Without & $0.56 \mathrm{Ba}$ & $0.36 \mathrm{Bb}$ \\
& With & $1.16 \mathrm{Aa}$ & $0.50 \mathrm{Ab}$ \\
\hline \multirow{2}{*}{$72 \mathrm{~h}$} & Without & $0.46 \mathrm{Ba}$ & $0.36 \mathrm{Ab}$ \\
& With & $0.90 \mathrm{Aa}$ & $0.30 \mathrm{Ab}$ \\
\hline \multirow{2}{*}{$96 \mathrm{~h}$} & Without & $0.50 \mathrm{Ba}$ & $0.43 \mathrm{Aa}$ \\
& With & $1.16 \mathrm{Aa}$ & $0.43 \mathrm{Ab}$ \\
\hline
\end{tabular}

Means followed by the same letter, uppercase in the columns and lowercase in the lines, in each time of artificial aging, do not differ among themselves by the Tukey test at $5 \%$ probability. 

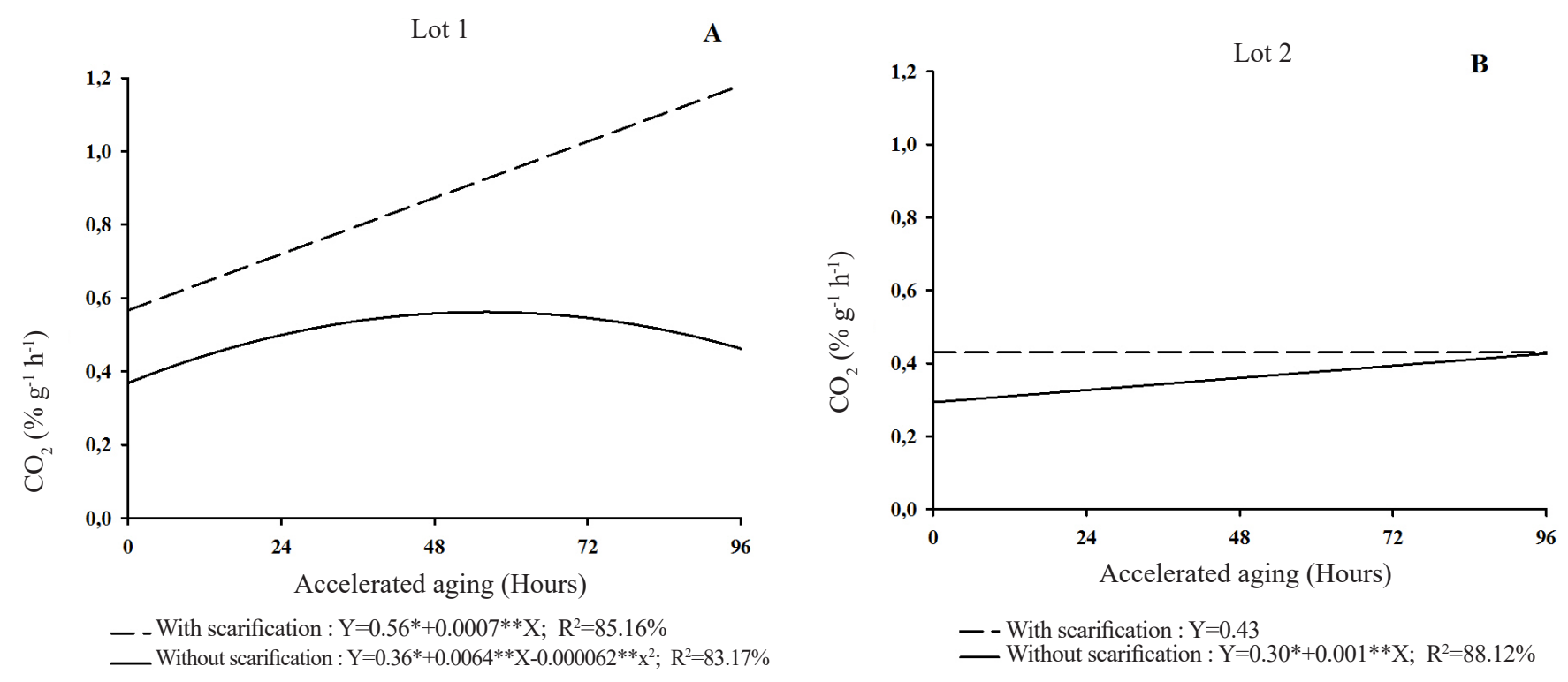

Figure 4. Respiratory activity evaluated in seed lots of hybrid Brachiaria cv. Mulato II without and with scarification submitted to accelerate aging.
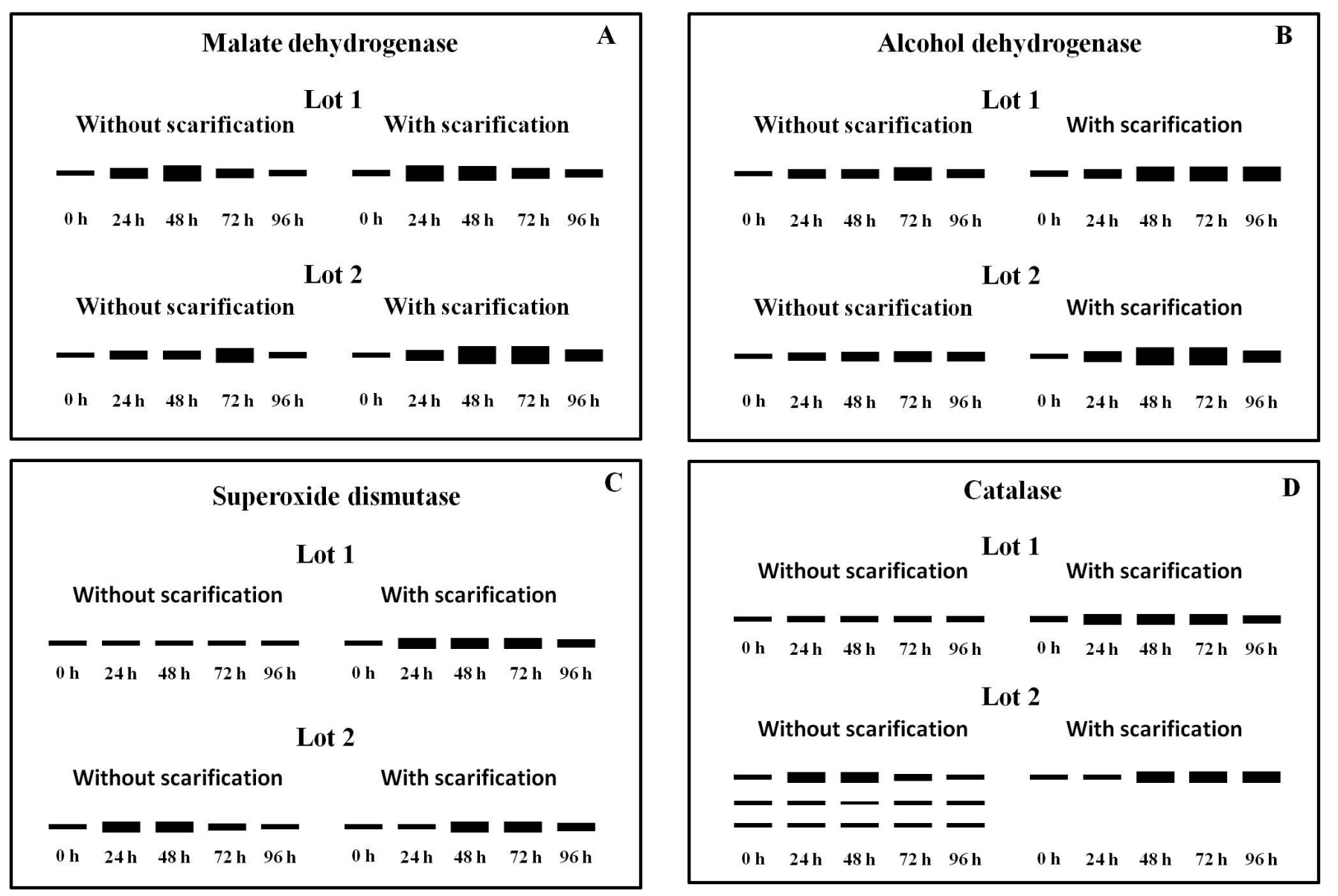

Figure 5. Zymogram for the expression of Malate dehydrogenase (A) and Alcohol dehydrogenase (B), Superoxide dismutase (C) and Catalase (D) enzymes extracted from hybrid Brachiaria cv. Mulato II seeds without and with scarification submitted to artificial aging. 
Breathing is the first metabolic activity observed in seeds after rehydration, from a rate close to zero to high values in a relatively short time, depending on the species (Dode et al., 2013). Both the respiration and the activity of enzymes, organelles and the synthesis of proteins are fundamental for the development of the process of germination and preparation for the subsequent growth of the embryo. Thus, in the same period of time, seeds of higher vigor generally present higher respiration rates than those of lower vigor (Crispim et al., 1994; Dode et al., 2013).

For the isoenzymes Superoxide dismutase (Figure 5C) and Catalase (Figure 5D), increases in the expression of these enzymes were also observed during accelerated aging, for seed lots without and with scarification. The highest expression for SOD enzyme in Lot 1 was observed for the scarified seeds for up to $72 \mathrm{~h}$; No changes in the enzymatic profile were observed in the seeds without scarification. Differently, for Lot 2, an increase in the expression of this enzyme was observed in seeds without scarification up to $48 \mathrm{~h}$, with a decrease from $72 \mathrm{~h}$, Increase in expression occurred only after $48 \mathrm{~h}$ for seeds scarified (Figure 5C). Regarding the expression of the enzyme Catalase (Figure 5D), there was also a difference in the profile of this enzyme between the lots, without and with scarification. No changes were observed in the expression of Catalase extracted from the seeds without scarification in Lot 1. When scarified, an increase occurred after $24 \mathrm{~h}$. In Lot 2 , higher expression of the enzyme Catalase was observed in the different periods of exposure of seeds at high temperature and humidity between 24 and 48h (Figure 5D). Regard in the expression of the enzyme Catalase in the seeds without mechanical scarification, a lower activity was observed during the exposure to high temperature and humidity in relation to the scarified seeds, except for the appearance of isoforms that were not expressed in the scarified seeds.

The highest enzyme expressions were observed in the seeds that had part of their structures removed by the scarification process. With the removal of the superficial layers a greater respiratory activity was detected, that is, a greater gas exchange occurred, intensifying the deterioration of the seeds. This reinforces what was observed by Previero et al. (1998), Usberti and Martins (2007) and Santos et al. (2011), for Brachiaria seeds, which state that one of the causes of dormancy is gas impermeability, provided by the envelope layers of the seeds. Since the enveloping layers do not allow wide gas exchange, less is the action of free radicals in the embryonic tissues, justifying the low expression of the antioxidant enzymes.

The accelerated aging in temperature, relative air humidity and exposure times evaluated, assists in the assumption of being able to overcome dormancy (Vieira et al., 2004) present in the seeds of hybrid Brachiaria cv. Mulato II, given the germination increments obtained in the scarified seeds, besides highlighting the quality differences between the lots. However, new studies must be carried out, since it was observed that the seeds without scarification had their germination capacity barely increased, compared to scarified seeds, only after $96 \mathrm{~h}$ of artificial aging, since a longer exposure time may favor the dormancy present in the species.

\section{Conclusions}

The exposure of the hybrid Brachiaria cv. Mulato II to accelerated aging at $42{ }^{\circ} \mathrm{C}$ and $98 \%$ of humidity for up to 96 hours does not alter its viability considering the tetrazolium test. Accelerated aging at $42{ }^{\circ} \mathrm{C}$ and $98 \%$ of humidity for up to 48 hours favors the germination of the scarified seeds of hybrid Brachiaria cv. Mulato II, increasing the expression of $\alpha$-amylase enzymes and reducing the electrical conductivity values. Loss of vigor occurs in scarified seeds of hybrid Brachiaria cv. Mulato II when exposed to accelerated aging at $42{ }^{\circ} \mathrm{C}$ and $98 \%$ of humidity from $96 \mathrm{~h}$ with consequent changes in enzymatic systems and with increased respiratory rate.

\section{References}

AGUSTINI, M.A.B.; MALAVASI, M.M.; STANGARLIN, J.R.; SCHUELTER, A.R.; MALAVASI, U.C.; SANTOS, H.S.; PEREIRA, R.W. Physiological performance and electrophoretic pattern of isoenzymes in Phaseolus vulgaris Lam. seeds treated with essential oil of Moringa oleifera Lam. Semina: Ciências Agrárias, Londrina, v.37, n.2, p.625-638, 2016. http://www.uel.br/revistas/uel/index.php/ semagrarias/article/view/20921/18583

ALFENAS, A.C. (Ed.). Eletroforese e marcadores bioquímicos em plantas e microrganismos. Viçosa, MG: UFV, 2006. 627p.

ALMEIDA, C.R.; SILVA, W.R. Comportamento da dormência em sementes de Brachiaria dictyoneura cv. Llanero submetidas às ações do calor e do ácido sulfúrico. Revista Brasileira de Sementes, v.26, n.1, p.44-49, 2004. http://www.scielo.br/scielo.php?script=sci arttext\&pid=S010131222004000100007\&lng=en\&nrm=iso

BRASIL. Ministério da Agricultura, Pecuária e Abastecimento. Regras para análise de sementes. Ministério da Agricultura, Pecuária e Abastecimento. Secretaria de Defesa Agropecuária. Brasília: MAPA/ACS, 2009. 395p. http://www.agricultura.gov.br/ arq_editor/file/2946_regras_analise_sementes.pdf

COSTA, C.J.; ARAUJO, R.B.; VILLAS BOAS, H.D.C. Tratamentos para a superação de dormência em sementes de Brachiaria humidicola (Rendle) Schweick. Pesquisa Agropecuária. Tropical, v.41, n.4, p.519-524, 2011. http://www.scielo.br/scielo.php?script=sci arttext\&pid $=$ S198340632011000400011\&lng=en\&nrm=iso 
CUSTÓDIO, C.C.; DAMASCENO, R.L.; MACHADO NETO, N.B. Imagens digitalizadas na interpretação do teste de tetrazólio em sementes de Brachiaria brizantha. Revista Brasileira de Sementes, v.34, n.2 p.334-341, 2012. http://www.scielo.br/pdf/rbs/v34n2/20.pdf

DIAS, M.C.L.L.; ALVES, S.J. Avaliação da viabilidade de sementes de Brachiaria brizantha (Hochst. ex A. Rich) Stapf pelo teste de tetrazólio. Revista Brasileira de Sementes, v.30, n.3, p.145-151, 2008. http://www.scielo.br/scielo.php?pid=S0101$31222008000300019 \&$ script $=$ sci_abstract\&tlng $=$ pt

DODE, J.S.; MENEGHELLO, G.E.; TIMM, F.G.; MORAES, D.M.; PESKE, S.T. Teste de respiração em sementes de soja para avaliação da qualidade fisiológica. Ciência Rural, v.43, n.2, p.193-198, 2013. http://www.scielo.br/pdf/cr/v43n2/a3613cr5997.pdf

EUCLIDES, V.P.B.; MONTAGNER, D.B.; BRABOSA, R.A.; VALLE, C.B., NANTES, N.N. Animal performance and sward characteristics of two cultivars of Brachiaria brizantha (BRS Paiaguás and BRS Piatã). Revista Brasileira de Zootecnia, v.45, n.3, p.85-92, 2016. http://www.scielo.br/scielo.php?script=sci_ arttext\&pid=S1516-35982016000300085

FRANCO, O.L.; RIGDEN, D.J.; MELO, F.R.; GROSSI-DE-SA, M.F. Plant $\alpha$-amylase inhibitors and their interaction with insect $\alpha$-amylases Structure, function and potential for crop protection. European Journal of Biochemistry, v.269, n.2, p.397-412, 2002.http:// onlinelibrary.wiley.com/doi/10.1046/j.0014-2956.2001.02656.x/full

FREITAS, R.R.; CARVALHO, D.A.; ALVARENGA, A.A. Quebra de dormência e germinação de sementes de capim-marmelada (Brachiaria plantaginea (Link) Hitchc.). Revista Brasileira de Fisiologia Vegetal, v. 2, n. 2, p. 31-35, 1990. [N/A]

GASPAR-OLIVEIRA, C.M.; MARTINS, C.C.; NAKAGAWA, J. CAVARIANI, C. Duração do teste de germinação de Brachiaria brizantha cv. Marandu (Hochst. ex A. Rich.) Stapf. Revista Brasileira de Sementes, v.30, n.3, p.30-38, 2008. http://www.scielo.br/scielo. php?script $=$ sci_arttext\&pid=S0101-31222008000300005

LACERDA, M.J.R.; CABRAL, J.S.R.; SALES, J.F.; FONTES, A.J. Superação da dormência de sementes de Brachiaria brizantha cv. "Marandu". Semina: Ciências Agrárias, v.31, n.4, p.823-828, 2010. http://www.uel.br/revistas/uel/index.php/semagrarias/article/ download/7589/6677

MARCHI, C.E.; FERNANDES, C.D.; ANACHE, F.C.; JERBA, V.F.; FABRIS, L.R. Quimio e termoterapia em sementes e aplicação de fungicidas em Brachiaria brizantha como estratégias no manejo do carvão. Summa Phytopathologica, v.34, n.4, p.321-325, 2008. http://www.scielo.br/scielo.php?pid=S0100$54052008000400004 \&$ script $=$ sci_abstract\&tlng $=$ pt

MARTINS, L.; SILVA, W.R. Efeitos imediatos e latentes de tratamentos térmico e químico em sementes de Brachiaria brizantha cultivar Marandu. Bragantia, v.62, n.1, p.81-88, 2003. http://www. scielo.br/pdf/brag/v62n1/18504.pdf

MESCHEDE,D.K.;SALES,J.G.C.;ALESSANDRO,L.B.;SCAPIM, C.A.; SCHUAB, S.A. Tratamentos para superação da dormência das sementes de capim-braquiária cultivar Marandu. Revista Brasileira de Sementes, v.26, n.2, p.76-81, 2004. http://www.scielo.br/scielo. php?script $=$ sci_arttext\&pid=S0101-31222004000200011
OLIVEIRA, A.S.; NERY, M.C.; RIBEIRO, K.G.; ROCHA, A.S.; CUNHA, P.T.; PIRES, R.M.O. Methodological adjustments to the vigor tests in Brachiaria brizantha Marandu cultivar seeds. International Journal of Current Research, v.8. n.2, p.2646626470, 2016. http://www.journalcra.com/article/methodologicaladjustments-vigor-tests-brachiariabrizantha marandu-cultivar-seeds

PEREIRA, A.M.; ABRANTES, F.L.; MACHADO-NETO, N.B.; CUSTÓDIO, C.C. Ar seco e aquecido no processo de dormência e germinação de sementes de Urochloa humidicola. Colloquium Agrariae, v.10, n.1, p.9-25, 2014. http://revistas.unoeste.br/revistas/ ojs/index.php/ca/article/view/983/1168

PREVIERO, C. A.; GROTH, D.; RAZERA, L. F. Dormência de sementes de Brachiaria brizantha (Hochst. Ex A. Rich) Stapf. armazenadas com diferentes teores de água em dois tipos de embalagens. Revista Brasileira de Sementes, v.20, n.2, p.392397, 1998. http://www.abrates.org.br/revista/artigos/1998/v20n2/ artigo26.pdf

QUADROS, D.G.; ANDRADE, A.P.; OLIVEIRA, G.C.; OLIVEIRA, E.P.; MOSCON, E.S. Componentes da produção e qualidade de sementes dos cultivares marandu e xaraés de Brachiaria brizantha (Hochst. ex A. Rich.) Stapf colhidas por varredura manual ou mecanizada. Semina: Ciências Agrárias, v.33, n.5, p.2019-2028, 2012. http://www.uel.br/revistas/uel/index.php/semagrarias/article/ view/9712/11581

RAMOS, M.J.M.; VITAL, A.R. Levantamento de sistema de produção, problemas e demandas da agropecuária do estado de Mato Grosso. Revista Brasileira de Agropecuária Sustentável, v.6, n.1, p.59-63, 2016. http://www.rbas.com.br/index.php/rbas/article/ view/307

RICAURTE, J.; RAO, I.M.; MENJIVAR, J.C. Estrageias de enraizamiento de genotipo Brachiaria en suelos ácidos y de baja fertilidad en Colombia. Acta Agronómica, v.56, n.3, p.107-115, 2007. http://www.revistas.unal.edu.co/index.php/acta_agronomica/ article/view/1032/1509

SALLUM, M.S.S.; ALVES, D.S.; AGOSTINI. E.A.T.; MACHADO NETO, N.B. Neutralização da escarificação química sobre a germinação de sementes de Brachiaria brizantha cv. 'Marandu'. Revista Brasileira de Ciências Agrárias, v.5, n.3, p.315-321, 2010. http://www.agraria. pro.br/sistema/index.php?journal=agraria\&page=article\&op=viewArticle\&path $\% 5 \mathrm{~B} \% 5 \mathrm{D}=$ agraria_v5i3a603

SANTOS, L.D.C.; BENETT, C.G.S.; SILVA, K.S.; SILVA, L.V. Germinação de diferentes tipos de sementes de Brachiaria brizantha cv. BRS Piatã. Bioscience Journal, v.27, n.3, p.420-426, 2011. http:// www.seer.ufu.br/index.php/biosciencejournal/article/view/8073

SILVA, L.M.S.; TORRES, F.E.; GARCIA, L.L.P., MATTOS, E.M.; TEODORO, P.E. Tratamentos para quebra de dormência em Brachiaria brizantha. Revista de Ciências Agrárias, v.37, n.1, p.37-41, 2014. http://www.scielo.mec.pt/scielo.php?script=sci arttext\&pid=S0871018X2014000100006\&lng=pt\&nrm=iso

TEODORO, M.S.R.; COSTA, K.A.P.; DIAS, F.J.S.; SIMON, G.A.; SAENZ, E.A.C.; SEVERIANO, E.C.; CRUVINEL, W.S. Composição bromatológica dos capins marandu e mulato II submetidos a diferentes alturas de resíduo. Global Science and Technology, v.5, p.137-146, 2012. http://rv.ifgoiano.edu.br/ periodicos/index.php/gst/article/view/526 
USBERTI, R.; MARTINS, L. Sulphuric acid scarification effects on Brachiaria brizantha, B. humidicola and Panicum maximum seed dormancy release. Revista Brasileira de Sementes, v.29, n.2, p.143-147, 2007. http://www.scielo.br/scielo.php?script=sci_ arttext\&pid=S0101-31222007000200020

VIEIRA, H.D.; SILVA, R.F.; BARROS, R.S. Efeito de diferentes temperaturas sobre a dormência fisiológica de sementes de braquiarão [Brachiaria brizantha (Hochst. ex A. Rich.) Stapf.]. Revista Brasileira de Sementes, v.20, n.2, p.84-88, 1998. http:// www.abrates.org.br/revista/artigos/1998/v20n2/artigo14.pdf
ZUFFO, AL.; ANDRADE, F.A.; SILVA, L.M.A.; MENEZES, K.O.; SILVA, R.L.; PIAUILINO, A.C. Revista Ceres, v.61, n.6, p.948-955, 2014. http://dx.doi.org/10.1590/0034-737X20146106009

WHITEMAN, P. C.; MENDRA, K. Effects of storage and seed treatments on germination of Brachiaria decumbens. Seed Science and Technology, v.12, p.233-242, 1982. http://agris.fao.org/agrissearch/search.do?recordID $=$ XE8282028 